\title{
Government-NGO Partnerships for International Development Cooperation: A Case Study of South Korea
}

\author{
HYUK-SANG SOHN ${ }^{*}$ AND SOWI KIM ${ }^{* *}$
}

\begin{abstract}
At the HLF-3 in Accra in 2008, developed and developing countries recognized civil society as an independent development actor in its own right, and they agreed to create a legal and institutional environment enabling CSO contributions to development. The Korean government also announced the Plan for the Advancement of ODA in 2010, which committed it to an unprecedented increase in the volume of NGO assistance and called for methods of multidimensional cooperation with NGOs. Against this backdrop, this paper aims to analyze the government-NGO partnership for development cooperation in Korea. After reviewing the mechanisms of OECD DAC members' partnerships with their NGOs and then Korean government-NGO partnerships in a comparative perspective, we conclude that both the Korean government and development NGOs are still facing many challenges for better partnership. For NGOs, these are accountability and sustainability issues, a tendency toward service delivery, proselycizing activities of Christian faith-based organizations, and a lack of capacity. For the government, it is uncertainty about its public commitment, an unclear vision and philosophy regarding ODA, an insufficient civil society partnership program, and a need for clear policy objectives for NGO support programs.
\end{abstract}

Keywords: Korea, International Development Cooperation, OECD DAC, ODA (Official Development Assistance), Development NGOs, KOICA, Government-NGO Partnership.

- An earlier version of this paper was presented at the international workshop, "U.S.-Korea Dialogue on Strategies for Effective Development Cooperation," co-organized by the Asia Foundation and the Center for U.S.-Korea Policy in Seoul, Korea on October 17, 2011. This paper also builds on materials from "A Study on Government-Civil Society Partnership for Development Effectiveness (in Korean)," a prior research project commissioned by the KOICA in 2011.

** Professor, Graduate School of Public Policy and Civic Engagement; Director, Center for International Development Cooperation, Kyung Hee University;

E-mail: hsohn@khu.ac.kr

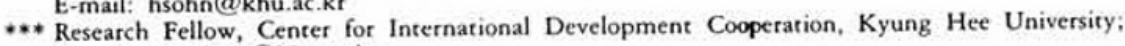
E-mail: sowi,kim@khu.ac.kr 
We will deepen our engagement with CSOs as independent development actors in their own right whose efforts complement those of governments and the private sector. We share an interest in ensuring that CSO contributions to development reach their full potential.

Accra Agenda for Action, Paragraph 20, HLF-4, 2008

\section{INTRODUCTION}

S ince joining the OECD DAC in January 2010, Korea has witnessed a strong surge of interest in cooperative development activity on the part of both government and civil society. Korea hosting the Fourth High Level Forum for Aid Effectiveness (HLF-4) in Busan in November 2011 provided momentum for discussions on how to improve Korean development practices. In 2010, the Prime Minister's Office announced the Plan for the Advancement of ODA, which included a commitment to increase the volume of Official Development Assistance (ODA) to $0.25 \%$ of GNI by 2015 (from $0.9 \%$ in 2009) and institute key policy reforms. Among them, strengthening the NGO partnership programs was a top priority. The Plan committed Korea to augmenting government assistance to NGOs for development cooperation by up to 90 billion Korean won by 2015, which is almost 10 times the amount that was allotted in 2010.

Against this backdrop, in 2011, Korean civil society also formed an umbrella organization, the Korean Civil Society Forum for International Development Cooperation (KoFID), and for the first time service-delivery-oriented development NGOs and advocacy NGOs for human rights, environment, and gender equality combined their efforts. Currently, both the government and civil society of Korea are confronting the possibility of a new and enlarged partnership in development cooperation.

Over the past decades, NGOs have become key development actors. Complementing or supplementing governmental and intergovernmental efforts for poverty reduction, NGOs have provided unique contributions to development cooperation. Recent development discourse tends to focus on "development effectiveness" rather than "aid effectiveness," which indicates that various issues, such as human rights, gender equality, and democracy lie at the core of development. ${ }^{1}$ Given that civil society has worked for these values for a long time, donors have started to recognize the participation of civil society as an indispensable element for development. At the Third High Level Forum on Aid Effectiveness in 2008, developed and developing countries recognized civil society as an independent development actor in its own right, in Paragraph 20 of the Accra Agenda for Action. There, they agreed to create a legal and institutional environment enabling 
civil society organization (CSO) contributions to development. ${ }^{2}$ In addition, most OECD DAC countries recognize civil society as a source of important partners, and they run several partnership programs. NGOs often participate in general policy processes, including policy formation, implementation, and evaluation (Advisory Group on Civil Society and Aid Effectiveness, 2007).

The Korean government also came to be aware of the importance of CSOs, which is evidenced by a series of administrative actions. The government drew up the policy document "General Guidelines for the Improvement of International Cooperation," and established the Committee for International Development Cooperation in the Prime Minister's Office in 2005, which claims many civil society activists as members, along with the chairing Prime Minister and other ministers. The ODA Bureau of the Prime Minister's Office announced the Plan for the Advancement of $O D A$ in 2010 , which committed the government to an unprecedented increase in the volume of NGO assistance and called for methods of multidimensional cooperation with NGOs. Furthermore, at the OECD DAC Working Group for Aid Effectiveness Meeting, held in Paris in July 2011, the Korean government emphasized the involvement of various development actors, including civil society, in "A New Global Compact for Development," based on comprehensive partnership. The importance of CSOs is also noted in the Korean government's position paper for the HLF-4.

However, Korea still faces various challenges in government-civil society partnerships. On the civil society side, issues of accountability and transparency, a one-sided tendency for service delivery, a large number of faith-based organizations with proselytizing agenda, and a low capacity level have to be dealt with. Although Korean civil society is usually described as one of the most vibrant sectors to lead the democratization movement during 1980s and 1990s (Joo et al. 2006), Korean development NGOs have a relatively short history and a lack of experience in the area of international development. On the government side, because the government has not been well aware of the importance of NGOs as development actors, it has not developed clear policy objectives, a clear vision, nor efficient programs for civil society partnerships.

In addition, academic research has been lagging, in regard not only to international development cooperation, but also to state-civil society relationships within the field. Against this backdrop, this paper aims to analyze the current situation of Korean development NGOs and their partnerships with the government. First, we will explore the theoretical background of the state-civil society relationship and then examine the mechanisms of leading donors' partnerships with their CSOs. An analysis of Korean government-NGO partnerships will follow. In the concluding section, we will suggest some constraints and challenges that must be dealt with by Korean NGOs and the Korean government. 


\section{THEORETICAL BACKGROUND: GOVERNMENT-CIVIL SOCIETY RELATIONSHIPS IN DEVELOPMENT COOPERATION}

A general survey of theoretical debates on state-civil society relationships, ranging from liberal to radical perspectives, is beyond the scope of this paper. In the fieid of international development, there are divergent perspectives on the state-civil society relationship, depending upon which aspects are of focus. Here, we will discuss some of the most representative positions, including the governance approach, the new policy agenda, Michael Edwards' civil society theory, Alan Fowler's idea of development NGOs as a fourth position, and Ian Smillie's theoretical work.

From the perspective of the governance approach, state and civil society complement or supplement each other, in contrast to a state-centered viewpoint, which assumes that governments play a predominant role. Governance can be defined as a tangible or intangible ruling system based on a horizontal network, in which state, market, and civil society actors participate, based on transparent and democratic policies (Lee 2009). It can be also understood as a mechanism to compensate for government or market failure with societal power. Civil society here is one part of a tripartite system (state, market, and civil society), but is also separate from the other sectors. It consists of nonprofit and voluntary organizations that pursue social goods not included in public and private goods. Civil society actors serve not only as participants in government/market management, but also as watchdogs.

In this context, the Organization for Economic Cooperation and Development (OECD) has strongly recommended the participation of civil society in government policy making, implementation and evaluation $(2001,23)$. Also, in regard to "good governance," civil society boosts the quality of policy decision making, increases transparency and accountability, and builds public trust in government $(27-69)$.

During the 1970 s and 1980 s, state-led development approaches were not successful in eradicating poverty. Confronting rampant poverty in developing countries, bilateral and multilateral aid agencies pursued the "New Policy Agenda," which is a combination of neo-liberal economic policy and good governance emphasizing the complementary or supplementary role of NGOs in development cooperation. Based on the governance approach, this line of policy envisions development NGOs as efficient forces that can complement the government in terms of poverty reduction, social welfare and civil society development. At the same time, they are organizational actors with the potential to strengthen democratic processes (Lewis 1998). Without reversing the neo-liberal policy orientation of small government, policy makers supported NGOs in providing basic social services in developing countries. 
The details of this policy agenda vary from one donor agency to another; however, there are two common aspects of how NGOs are working with governments. One is as a preferred channel for social welfare-that is, acting as more efficient and cost-effective service providers than governments, giving better value-for-money, especially in reaching the poor. The other is political: as an integral component of a thriving civil society and an essential counterweight to state power, opening up channels of communication and participation (Edwards 1996).

Another school of thought emphasizes the voluntary and associational aspects of NGOs that are interacting with government. Michael Edwards conceives of civil society as a form of associational life, good society, and the public sphere. As a sphere of voluntary association, civil society plays a significant role in the development of the state. The synergy between a strong state and a strong civil society is one of the keys to continuing poverty reduction and development. Civil society makes a considerable contribution to improving the standard of living of the people in the South. Also, it supports the construction of independent voluntary organizations and, as a result, enables good governance and healthy democratic progress. As part of this process, civil society in donor countries buttresses accountability by complementing and monitoring governments and markets (Edwards 2004).

Differing from rather conventional views of the government-NGO relationship, which assume clear demarcations among the state, markets, and civil society and NGOs, Alan Fowler conceives of nongovernmental development organizations (NGDOs) as a springboard for cooperation and participation among the state, markets, and civil society. Fowler opines that NGOs consciously occupy a fourth position among those three sectors and that they cannot be fully understood to be part of any single sector. For example, NGDOs resemble states in that they pursue a public agenda; they might be seen as market actors because of their surplus generation and self-financing; and they associate with civil society in terms of their roots and the value-based traits and participatory methods they apply.

According to Fowler, NGDOs play at least four roles: negotiator, validator, watchdog and innovator. The goals and tasks associated with the fourth position are to ensure human rights entitlements by exacting compliance from duty bearers and to undertake activities that reduce overall risk in society or redistribute risk to those more capable of bearing it. What inspires and motivates NGDOs is "axiomatic values or ethics"-a humane understanding of, and personal commitment to, humane relationships and to a particular type of social order (Fowler 2000).

Focusing exclusively on government-NGO relations within the international development field, Ian Smillie depicts NGOs as supplements, complements, alternatives, critics and watchdogs in relation to government (Smillie 1994). Gover- 
Figure 1. NGDOS as the Fourth Position

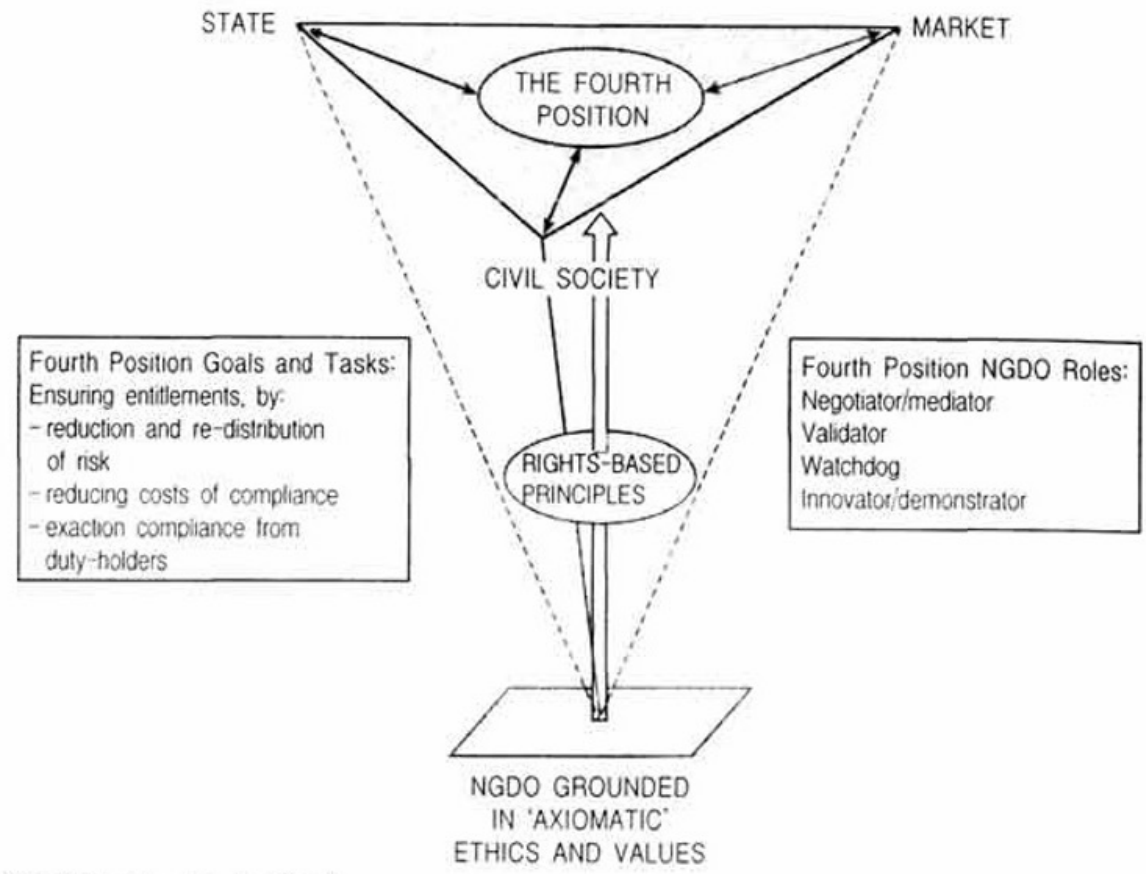

SOURCE: Alan Fowler(2000)

nments appreciate what NGOs are capable of, and they have established several funding schemes for NGOs, with government priorities in mind. In the early 1960s, grants to NGOs from governments of developed countries involved fewer conditions and had limited reporting requirements. In the mid-1990s, grants shifted toward contracts for the management of bilateral programs and projects. At first, these contracts were on a sole-source basis; however, later on, NGOs were encouraged to compete with each other and with private sector firms. Then came "output contracting," which indicated donors' growing interests in tangible outputs from aid projects (Smillie 1999).

With the increase of government reliance on NGOs, the political demand for accountability for government spending-whether directly by the governments themselves or through NGOs-was also rising. At the state level, tangible results from aid were an important measure; at the level of the NGOs, there were other accountability concerns. For the NGOs, balancing accountabilities was important, since they are accountable to individual donors, staff, the media, host governments overseas, counterparts and partner organizations, and beneficiaries (Smillie 1999). Smillie suggests that peer pressure among organizations and 
public pressure can ensure greater quality control, and donors' evaluations, combined with financial incentives, can enhance accountability $(1999,33)$.

While the theoretical perspectives explored so far have different points of views regarding the state-NGO relationship, they hold in common the fact that NGOs are no longer secondary actors in international development cooperation. However, the relevance of these perspectives to the Korean case differs. The "Fourth position" espoused by Alan Fowler is a distant target for Korean NGOs, which have been struggling to build their developmental capacities. The Korean government, as a newly emerging donor, does not share the pitfalls of the neo-liberal development policies faced by the OECD DAC countries during the 1980s and 1990s. Therefore, the New Policy Agenda is not an issue for Korea. Instead, Michael Edwards' idea of associational life can explain a great deal about the current state of Korean ODA partnerships, which reflect the strong voices of Korean civil society in terms of political and social rights. Considering the fact that Korea faces many obstacles simultaneously within both governmental and civil society sectors for achieving an "effective" partnership between them, what Ian Smillie described above can also be applied to these complexities. In the following section, we will review the OECD DAC countries' NGO partnership programs, before examining the case of Korea.

\section{A REVIEW OF OECD DAC COUNTRIES' NGO PARTNERSHIP PROGRAMS}

In the 1990s, development NGOs were recognized as "preferred channels" for development work by donor agencies and governments. The total aid to NGOs from DAC members has increased constantly from USD 4.7 billion in 2001 to USD 9 billion in 2009. This official support consists of two types: aid to NGOs and aid through NGOs. The former consists of core support for NGOs, which includes contributions used to fund NGOs' projects, while the latter consists of contributions for donor-initiated projects that are implemented by NGOs. As shown in Figure 2, while the volume of core aid has remained stable over the past years, an increase in earmarked aid implies that donors use NGOs mostly as implementing partners or contractors (DCD/DAC 2011).

However, we can see in Figure 3 that DAC members have differed in their ODA allocations to NGOs. While 11 countries spent over $20 \%$ of their ODA budgets for NGO support, 5 states allocated less than $5 \%$. For example, Ireland distributed over $37 \%$, while France spent only $1 \%$. This reflects the fact that NGOs occupy different positions in DAC member countries.

Donors have several funding mechanisms for supporting NGOs. These mechanisms include project/program support to national and international NGOs, calls for proposals at the headquarters level, core support, support to local organizations 
Figure 2. Total ODA to and Throvgh NGOs from DaC Members (2001-2009)

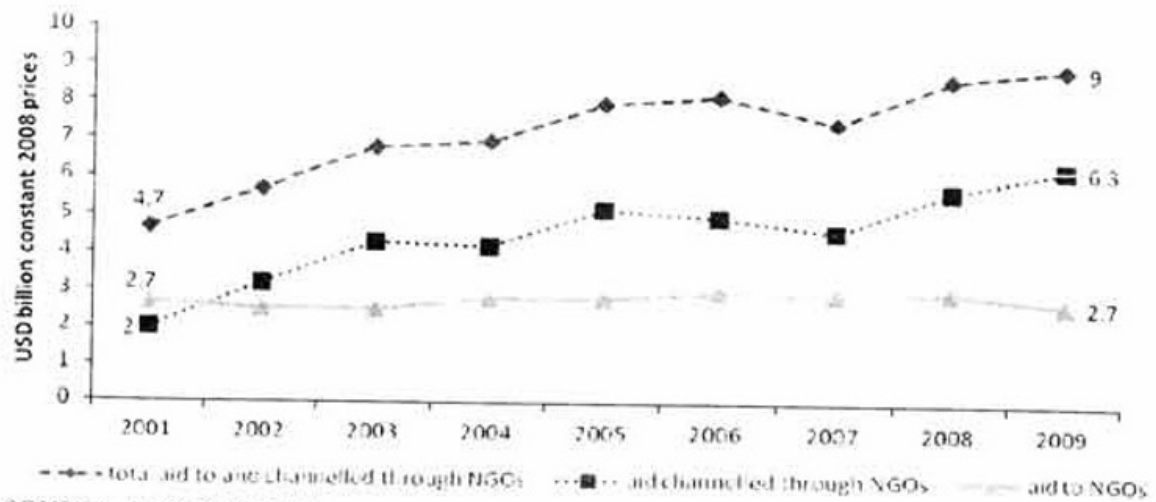

SOURCE: DCD/DAC 2011

Figure 3. Percentage of Bllateral. Oda Golng to and Through ngos in 2009

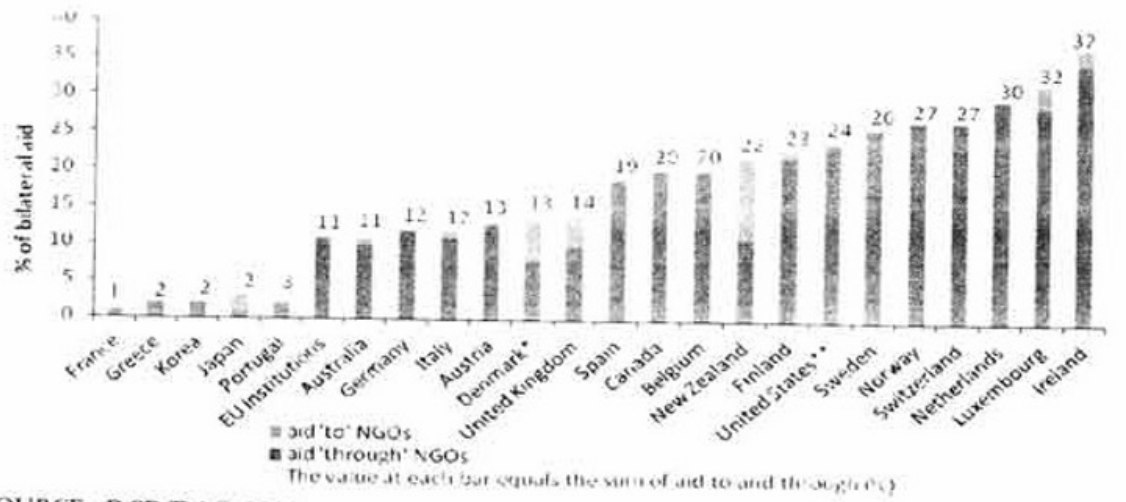

SOURCE: DCD/DAC 2011.

in partner countries, pooled funding, co-funding and emergency funding. The most common type is project and program support, which is useful for fulfilling specific development objectives by channeling aid through NGOs as intermediaries. Calls for proposals at the headquarters level also ensure the value of the donor's money, because they create a competitive environment among NGOs. Likewise, each mechanism has its strong point, and having a range of support mechanisms is in line with recommendations by the Advisory Group (DCD/DAC 2011).

Except for Korea and Greece, 22 DAC members apply more than 2 funding mechanisms (see Figure 4). The majority of donors use various types of systems: the EU uses 8 types, while the UK, Switzerland, Sweden, Norway, and Australia 
use 7. Given that diverse funding mechanisms are required for development work, Korea needs to devise a variety of systems.

Figure 4. Number of Funding Mechanisms by Donor

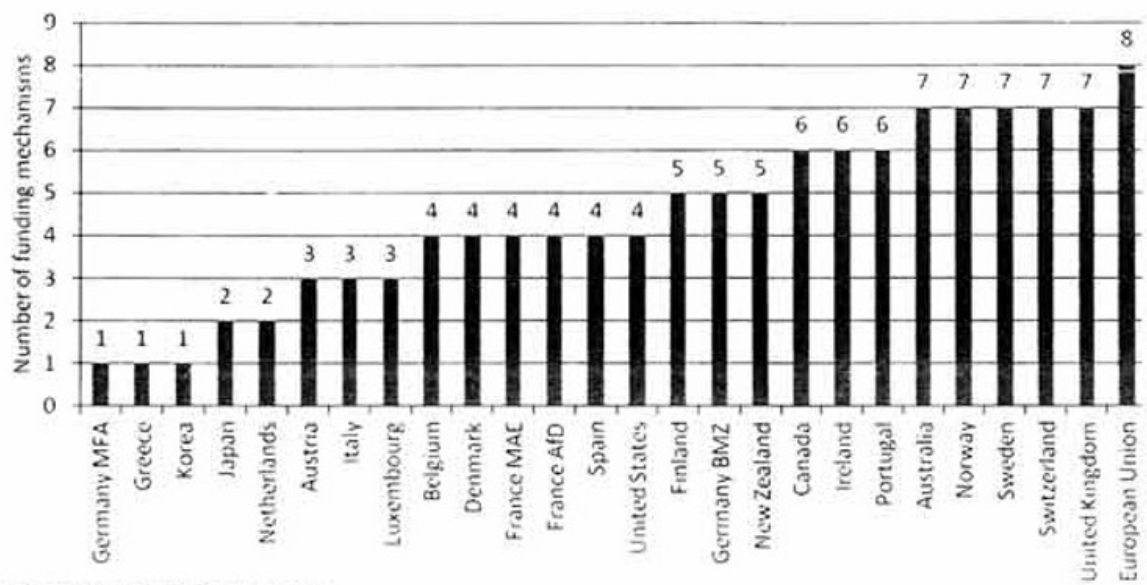

SOURCE: DCD/DAC 2011

Figure 5. Priorities of Civil. Society Cooperation

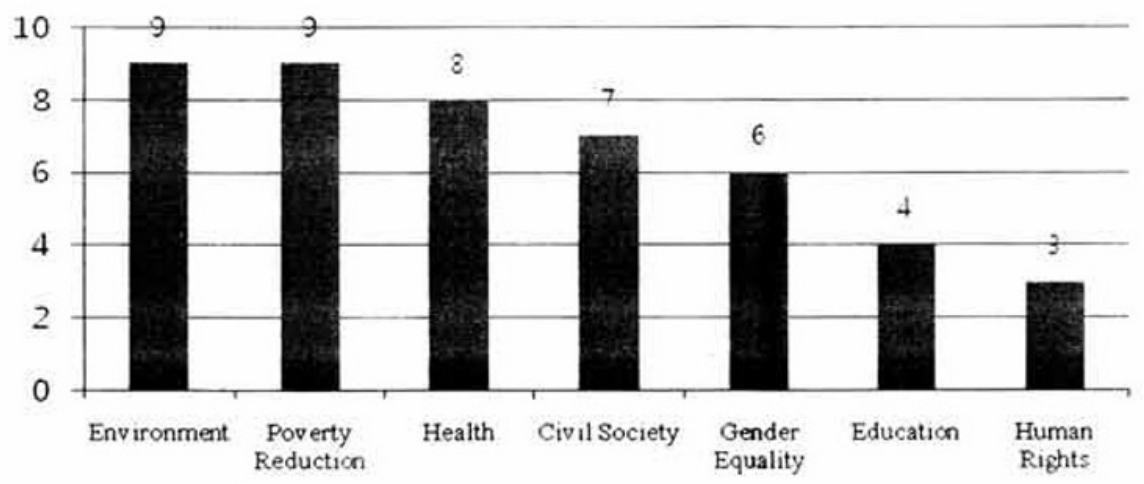

SOURCE: Sohn et al. 2011a.

Regarding the policy objectives of NGO partnerships, 16 out of 24 DAC members set priorities, whether explicitly or implicitly. According to a recent study (Sohn et al. 2011 a), environmental concerns and poverty reduction are the most common areas for civil society cooperation. However, when gender equality and human rights are taken into account as parts of civil society development, civil society development could be said to be the most frequent goal of civil society partnership. Recently, donors have given attention to new areas, 
but they still stress traditional areas of service delivery, such as health and education. Figure $S$ shows that donors focus on diverse areas, not simply on the economic growth of partner countries, when it comes to state-NGO partnership.

\section{KOREAN DEVELOPMENT NGOS: HISTORY AND ACTIVITIES}

The history of Korean development NGOs can be traced back to the 1950s. Following the Korean War, Korea was targeted to receive support from developed countries. During this period, missionaries and foreign aid organizations established organizations to help with the restoration and development processes. During the 1960s and 1970s, endogenous Korean development NGOs were founded. Many of them were faith-based, which was later the case for the majority of development NGOs in Korea. In the 1990s, Korean development NGOs flourished, and, as the economic development of Korea progressed successfully, a number of Korean development NGOs devoted themselves to the international community. The Korean Council for Overseas Cooperation (KCOC), established in 1999, reflects the growth of Korean development NGOs.

Since 2000, a series of international disasters has served as an impetus for vigorous official development assistance by Korean NGOs, especially in the form of emergency relief and reconstruction: the Afghanistan Crisis in 2001, the Iraq War in 2003, the tsunami in Southeast Asia in 2004, the earthquake in Pakistan in 2005, and the one in Haiti in 2010. At the same time. Korea International Cooperation Agency (KOICA)'s support to NGOs has increased and has become diverse, enabling more dynamic aid from Korean NGOs. Also, the private sector, including enterprises and foundations, began to support NGOs (Sohn and Yoo 2009; Sohn et al. 2010).

As shown in Table 1 and Figure 6 below, Korean development NGOs have increased steadily in size and number throughout the years. In 2010, member organizations of the KCOC more than doubled compared to the year 2000. Considering that there are non-KCOC member NGOs supported by KOICA, the Community Chest of Korea, or the Samsung Dream Scholarship Foundation, the number of current Korean development NGOs can be estimated to be at least 140. Also, according to a survey by Sohn et al., the annual project expenditures of Korean development NGOs have been rapidly enlarged, from 300 billion won in 2005 to 600 billion in 2009 (2010, 86). Even though the respondents to the survey included only a portion of KCOC members ( 50 organizations out of 74 responded), we can infer from the results that the annual spending for projects increased dramatically during that time period.

Interestingly, as evidenced by the survey, there is a huge disparity between large and small organizations in the size of expenditures on overseas projects. 4 out of the 50 respondent organizations spend more than 10 billion won on 
Table 1. The Number of Member Organizations of the KCOC

\begin{tabular}{cccccccccccc}
\hline Year & 2000 & 2001 & 2002 & 2003 & 2004 & 2005 & 2006 & 2007 & 2008 & 2009 & 2010 \\
\hline KCOC members & 31 & 33 & 35 & 36 & 40 & 44 & 48 & 58 & 62 & 63 & 74 \\
\hline
\end{tabular}

SOURCE: Sohn et al. 2010.

Figure 6. Annual. Project expenditures of 50 KCOC Members

(units: million Korean won)

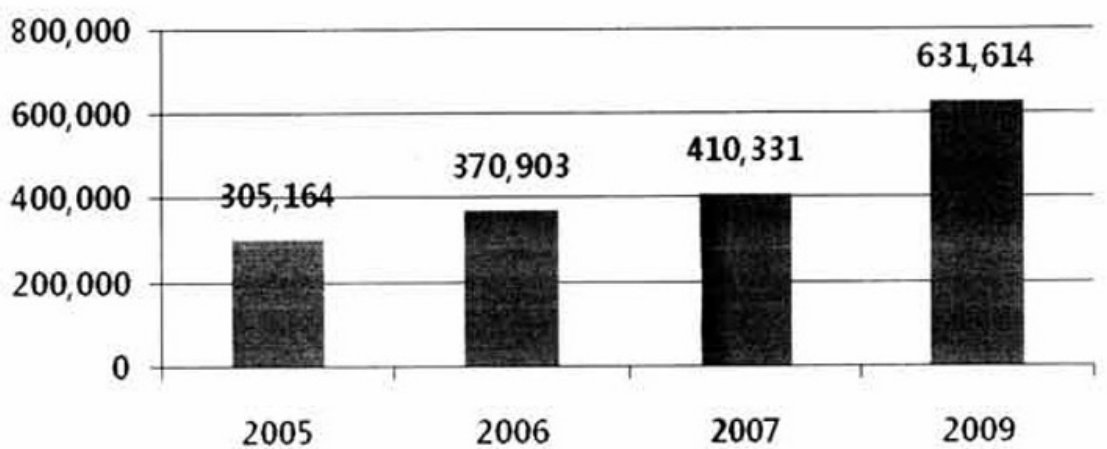

SOURCE: Sohn et al. 2010

overseas projects, and their spending added up to $78 \%$ of the total expenditures by all 50 organizations. The other 28 organizations, constituting $56 \%$, spend less than $5 \%$ of their total budget son overseas projects. It can be concluded that the Korean development NGO community is made up of a small number of large organizations and a large number of small organizations (Sohn et al. 2010).

In regard to development projects, community development takes its place at the top of the agenda $(39.7 \%)$, followed by health care $(7.2 \%)$, and education $(6.9 \%)$. However, in terms of the number of overseas projects, education ranks second. The difference between the positions of education is due to the fact that its projects consist of many small-scale activities, such as tuition support and scholarship support.

Another salient feature of Korean development NGOs is that the majority of them were established based on faith, be it Christianity, Catholicism or Buddhism, as shown in Figure 8. Faith-based organizations (FBOs) tend to implement relief, development, education and advocacy activities based on their beliefs, and these lines of thoughts are explicitly expressed in their official mission statements. ${ }^{3}$ Since Koreans have had fewer humanitarian experiences than their European counterparts, it is understandable that religiousness has played a great role in the advancement of Korean development NGOs. However, their religiousness can be a double-edged sword, in that they tend to use development work as an instrument 
to furcher their missionary evangelism worldwide (Sohn and Yoo 2009). ${ }^{4}$ Also, when FBOs make religious commitment and devotion their top priorities, their capacity enhancement and professionalism are likely to be left behind.

Figtire 7. KCOC MFmbers Expfnidturfs on Overseas Projects in 2009

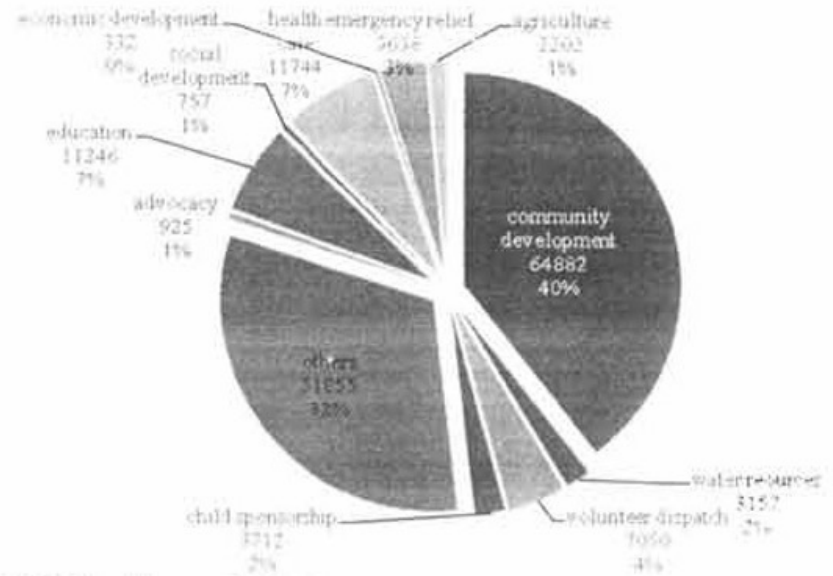

- comounaty developinent

- water recurces

- volunter dispatidi

- child sponsorsthy

- thers

- advocacy

- education

- wocial develoyment

chealth care

- economic develigentat

vetreriency relie?

arenculture

SOURCE: Sohn et al. 2010.

Figlire 8. Classification of Kurfan Development NGOS By Reilgiousness

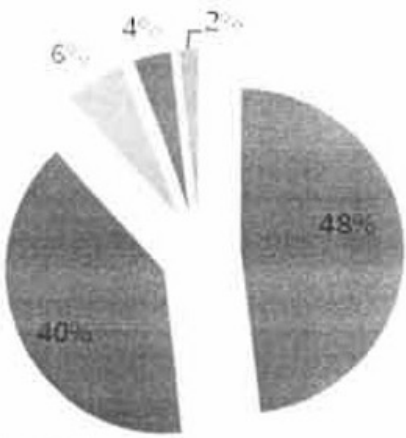

Non-religious

- Christianism

Won Buddhism

Catholicism

Buddhism

SOURCE: KCOC 2010.

Despite these drawbacks, development organizations in Korea are seen as lively and highly knowledgeable, according to the Special Review of OECD/DAC conducted in 2008. The sector is well coordinated and growing, and the government, which already has a generally open relationship with civil society, would benefit from continued engagement in policy dialogues with it $(2008,12)$. In the following section, we will explore in further detail the government-NGO partnership in Korea. 


\section{KOREA'S NGO PARTNERSHIP PROGRAMS AND ODA POLICY}

In 2003, with the slogan "participatory government" in Roh Moohyun's administration, the Presidential Commission on Sustainable Development and the Prime Minister's office tried to reform Korean ODA. As a part of the reform, in 2006, the International Development Cooperation Committee was established under the authority of the Prime Minister's office. The committee was to deliberate on Korean development policy making, strategic planning, and evaluation. Furthermore, efforts in the areas of policy and legislation have continued, which was evidenced by the Plan for Improving International Development Cooperation in 2005, the ODA Mid-Term Strategy in 2007, and the Plan for the Advancement of $O D A$ in 2011. In those documents on strategy, the Korean government emphasized the cooperation of civil society to enhance development effectiveness and raise the sustainability of its ODA.

The current objective of the KOICA NGO Support Program is to complement inter-governmental international cooperation efforts. As indicated in several ODA strategy plans, however, there is no coherence regarding the objectives of government-NGO cooperation and the roles of NGOs (shown in Table 2). Multiple sets of goals can be found in each official document; these include meeting the Basic Human Needs (BHN) of the people, contributing to the Millennium Development Goals (MDGs), complementing government, and increasing the effectiveness of international development cooperation. Considering that other leading donors set priorities on poverty reduction, strengthening civil society in partner countries, building capacity for Southern CSOs, cooperating with the private sector, and promoting democracy, human rights and governance, KOICA's stance appears to be government-centric-that is, it perceives NGOs

Table 2. KoICA's Objectives for the NGo Support Program

\begin{tabular}{|c|c|}
\hline Document & Objective \\
\hline $\begin{array}{l}\text { Mid-Term Strategy } \\
\text { for Grant Aid } \\
\text { (October 2007) }\end{array}$ & $\begin{array}{l}\text { "Meeting the BHN of poor people in developing countries and contributing } \\
\text { to the MDGs through extensive support to projects in which NGOs have } \\
\text { a comparative advantage." }\end{array}$ \\
\hline $\begin{array}{l}\text { KOICA Website } \\
\text { (October 2010) }\end{array}$ & $\begin{array}{l}\text { "Aid channeled through NGOs complement that of the government by } \\
\text { utilizing their expertise, experience and the ties they have formed in } \\
\text { communities in developing countries." }\end{array}$ \\
\hline $\begin{array}{l}\text { Guidebook on the } \\
\text { NGO Support } \\
\text { Program }(2010)\end{array}$ & $\begin{array}{l}\text { "Raise the effectiveness of international development cooperation through } \\
\text { building partnerships between the government and NGOs; complement } \\
\text { government development efforts by utilizing NGO's expertise, experience } \\
\text { in international development and the ties with local community in developing } \\
\text { countries." }\end{array}$ \\
\hline
\end{tabular}

SOURCE: Sohn et al. 2010. 
as instruments for achieving governmental goals. Furthermore, although KOICA has explicitly stated that NGOs serve as a complement and supplement to Korean ODA, the ways in which the NGO Support Program is linked with KOICA's overall ODA projects have not been elucidated.

Nevertheless, it seems that KOICA has policy coherence in regard to the NGO Support Program, in conjunction with its overall foreign aid policy. Strategic plans in 2005 and 2007 clearly indicated that it would strengthen its partnership with the private sector, increase the participation of development NGOs, and support them in building capacity. By 2010, most of these goals had been realized (Sohn et al. 2010). Furthermore, to cooperate with civil society more effectively, as expressed in the Plan for the Advancement of ODA in 2010, KOICA now seeks to establish blueprints for a KOICA-civil society partnership, commissioning several research projects, including an NGO support program, a capacity-building program, and a public-private partnership.

Table 3. Pol.icy Coherence Regarding the ngo Support Program

\begin{tabular}{|c|c|c|}
\hline $\begin{array}{c}2005 \text { Plan for Improving } \\
\text { International Development } \\
\text { Cooperation }\end{array}$ & $\begin{array}{c}2007 \text { Mid-Term Strategy for } \\
\text { Grant Aid }\end{array}$ & Policies Implemented in 2010 \\
\hline $\begin{array}{l}\text { Strengthen partnership with } \\
\text { the private sector } \\
\text { Increase the participation of } \\
\text { development NGOs: will } \\
\text { provide more assistance to } \\
\text { development NGOs and } \\
\text { diversify NGO support } \\
\text { mechanisms. }\end{array}$ & $\begin{array}{l}\text { - Provide more support for the } \\
\text { private sector } \\
\text { Provide diverse support } \\
\text { mechanisms for privare } \\
\text { organizations } \\
\text { - Urilize the expertise of private } \\
\text { organizations and prioritize } \\
\text { support for areas with } \\
\text { comparative advantage } \\
\text { "Increase support for private } \\
\text { organizations to build } \\
\text { capacicy } \\
\text { - Gradually increase the } \\
\text { number of NGO overseas } \\
\text { volunteers }\end{array}$ & $\begin{array}{l}\text { Support toward NGOs was } \\
\text { pledged to increase to } 5 \% \text { of } \\
\text { total ODA by 2015 } \\
\text { - New programs were } \\
\text { launched, such as the } \\
\text { Public-Private Partnership } \\
\text { (PPP) Program, the Air Ticket } \\
\text { Solidarity Levy Program and } \\
\text { the Program on Raising } \\
\text { Development Awareness } \\
\text { Support was provided for } \\
\text { capacity-building programs } \\
\text { through KCOC } \\
\text { - The number of NGO } \\
\text { Overseas Volunteers was } \\
\text { increased }\end{array}$ \\
\hline
\end{tabular}

SOURCE: Sohn et al. 2010.

As an implementing organization, KOICA executes civil society cooperation policies, mainly through the NGO Support Program. Beginning in 1995, KOICA began funding Korean NGOs involved in overseas projects and instituted the Non-Governmental Organization Team for managing the cooperation of the two sides. In 2011, the team expanded to the office level and changed its name to the Public-Private Partnership Office, which could mean that KOICA 
is considering cooperation with civil society more seriously than before. The basic stance of KOICA concerning development NGOs is that they act as a mechanism to make up for a lack of official assistance work at the governmental level and to support overseas aid work (Sohn and Yoo 2009).

From 1995 to 2006, KOICA has experienced a gradual increase of the NGO Support Program in scale and project numbers. Except in 1998 and 1999, when the Asian financial crisis drastically shook Korea's economy, the volume of NGO assistance has steadily increased. In 2007, the total budget exceeded 2 billion won for the first time, as part of the effort to expand public-private partnerships. In 2008, it amounted to 5.8 billion won, more than double the amount in the previous year. In 2010, in the Plan for the Advancement of ODA, the Korean government pledged to augment NGO support in the budget, and the following year the total budget rose to over 10 billion won.

Figure 9. Funds Given to thie NGO Support Program (1995-2011) (unit: a million won)

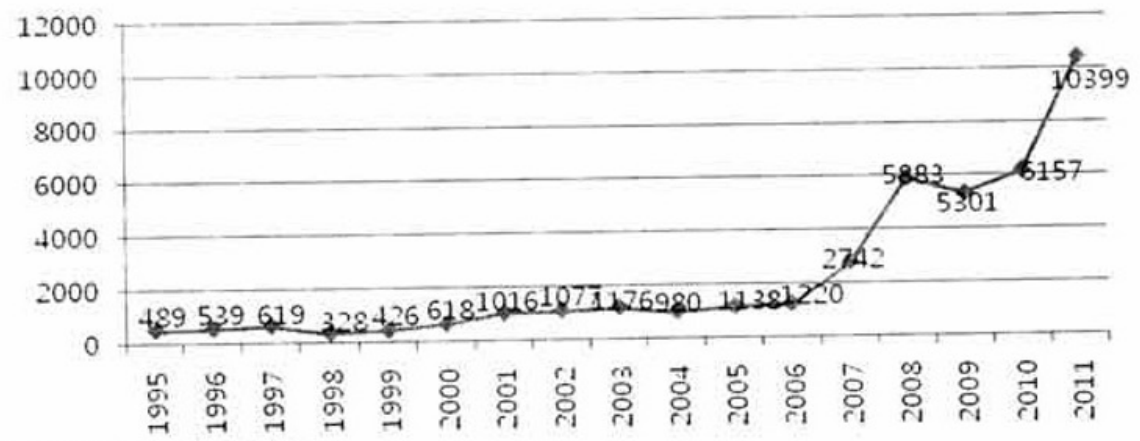

Source: Sohn et al. 2010.?

Furthermore, the number of projects supported by the program has risen gradually for the last 16 years, except in 2004, when the overall KOICA budget decreased. In 1995, 19 projects were implemented in 19 countries; in 2011, the number rose to 101 projects, involving 64 NGOs and 29 countries. It can be noted that the number of NGOs is increasing faster than the number of countries where they are operating, because Korean NGOs have accumulated enough capacity to initiate more projects in countries where they are already working, rather than tackling new challenges in other countries.

Besides the NGO Support Program, the mechanisms for KOICA's civil society cooperation include the Invitational Training Program, the Korea Overseas Volunteers Program, Emergency Relief, Expertise Dispatch, and Air Ticket Solidarity Contributions. While implementing these programs, KOICA focuses on specific areas of development: education, health, governance, rural development, 
ICT, industry and energy, environment, disaster relief and reconstruction, MDGs, and climate change. However, because of the multidimensional nature of poverty, eliminating poverty cannot succeed solely by fulfilling $\mathrm{BHN}$; it must be achieved through combined economic, political, and socio-cultural approaches. Therefore, other areas such as human rights, sustainable development, democracy and alternative development must be supported as well.

Figive 10. Number of Projects, NGOS and Partner Countries Supported Through the Support Program (1995-2011)

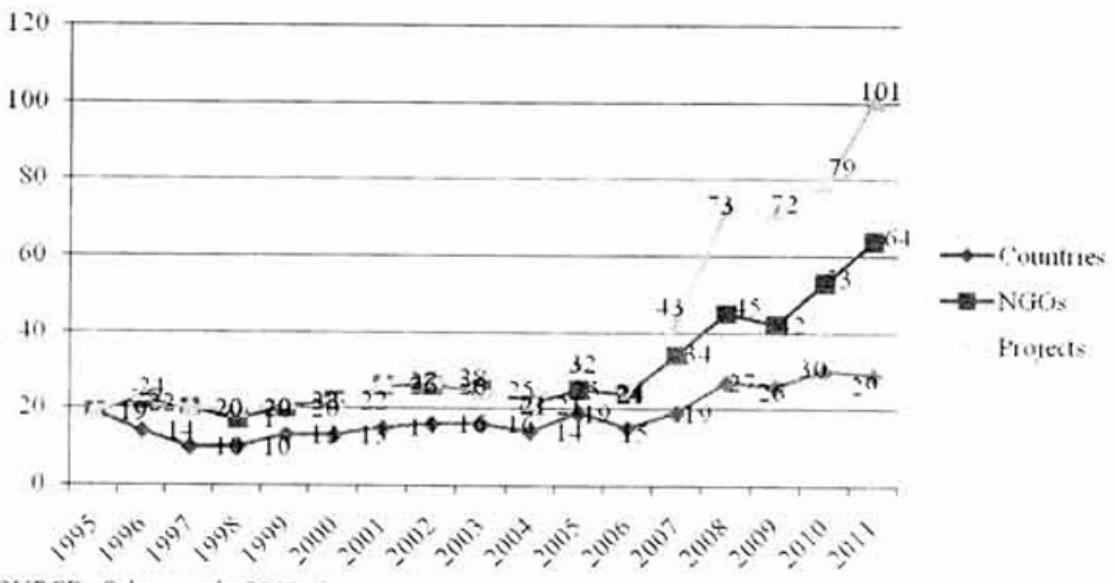

SOURCE: Sohn et al. 2011a,"

As mentioned above, Korea's government-civil society partnership faces several constraints at the institutional level. While KOICA's budget for civil society cooperation is likely to expand in upcoming years, KOICA does not yet have a strategic plan that covers the philosophical framework, direction, objectives, and projects for partnerships. ${ }^{7}$ Without clear, shared goals, it is axiomatic that the plan will not be successful; with such goals, it could be.

\section{CONCLUDING REMARKS: CHALLENGES AND OPPORTUNITIES}

Although statistics show that Korean development NGOs have experienced rapid growth in the number of their projects, they face challenges involving accountability and sustainability issues, an overwhelming tendency toward service delivery, a great number of faith-based organizations with proselytizing agenda, and a lack of capacity.

As discussed earlier, the majority of Korean development NGOs receive a 
large amount of government funds as their primary support. Dependency on resources from public authorities brings two thorny issues to the NGO-state relationship; accountability ${ }^{8}$ and sustainability. First of all, as NGO dependence on public money grows, NGOs face new pressures calling for greater accountability for the impact and quality of programs. They are required to demonstrate the results of their work to assure donors that their money produces successful outputs and outcomes (Lindenberg and Bryant 2001). Also, by the same token, NGOs are asked to be legitimate, transparent, and credible. Therefore, NGO self-regulatory mechanisms have come to be a crucial means for demonstrating these values. Codes of conduct are one example: statements of principles or standards of performance to which organizations voluntarily agree and against which they can be evaluated. Though they are not mandatory, codes of conduct are already widely accepted by several major NGOs and NGO associations, such as the US PVO Member Association. Inter Action, the International Red Cross, and the Australian Council for International Development (ACFID). These organizations either abide by NGO standards or adopt codes of conduct to warrant their legitimacy.

The KCOC, too, established its code of conduct in 2007, in cooperation with civil society personnel, including several professors and representatives of Korean major development NGOs. The code sets the values, principles, and standards for governance, management, financial control and reporting, which development NGOs should share and with which they should comply (KCOC 2007). However. the code of conduct of the KCOC is not taken seriously by NGO partners. Because at the moment there is no proper mechanism to evaluate the performance and transparency of Korean development NGOs, they are expected to prove their accountability to the public in other ways.

Another problem resulting from dependency on government support is the sustainability of organizations and their work. Since donor agencies and governments have continued to expand the ODA budget for NGO support, it can be said that NGOs have become crucial partners for donors in implementing international development policy. However, at the same time, NGOs might exist merely as service contractors, lingering on government support. The financial independence of NGOs is fundamental, not only for organizational sustainability, but also for the sustainability of development work. Without NGOs' having sufficient resources on their own, there is always a possibility that donors' intentions will get in the way.

Second, although the number of development NGOs has dramatically increased over the last few decades, Korean civil society's engagement with advocacy is not yet reflected in the field of development cooperation. Korean development NGOs focus largely, if not exclusively, on service delivery rather than advocacy.? This trend in the field of international development does not follow the general features of Korean civil society. According to the Civil Society Index of CIVICUS, 
Korean civil society organizations have focused on advocacy activities, such as holding the state and business sector accountable and demanding transparency. Once the most trusted institutions among all major public and social institutions, Korean advocacy NGOs have tended to utilize the "nationwide solidarity" strategies of agenda setting and political mobilization, which have been extremely effective and efficient (Joo et al. 2006). There are, of course, some advocacy development NGOs, such as ODA W'atch, People's Sulidarity for Participatory Democracy (PSPD), and Global Call to Action against Poverty Korea, but their advocacy work is in an inchoate state. That is because civil society has treated this interest in advocacy as marginal. In Korea, a few major NGOs tend to cover a wide range of issues, from politics and economics to culture. Furthermore, with limited financial and human resources, the Korean development community lacks an enabling environment for advocacy work (Han 2009).

Third, the majority of Korean development NGOs are faith-based organizations. As shown in Figure 8, $52 \%$ of them are based on religion, and of this group over $70 \%$ are Christian. Of these, there are a number of conservative ones focusing on personal faith and proselytism rather than social issues. Even though it is true that FBOs contributed much to the advancement of Korean development NGOs, their religiousness sometimes acts as a constraint in the field (Han 2010; Sohn et al. 2009).

Lastly, with a short history and a lack of experience, Korean development NGOs have to deal with the challenges of capacity building. According to a survey conducted by Sohn et al., the majority appears to have organizational visions and missions, and well formulated strategies and objectives. However, these values are not widely shared among their staff and remain inflexible in an ever-changing development environment. Also, although they have organizational procedures, half of small-to medium-sized development NGOs fail to complete monitoring and evaluation procedures. When it comes to the effectiveness, efficiency, accountability, and transparency of NGOs, a commitment to vision and mission and an abiding code of ethics are prerequisites. Therefore, to foster an environment of international development, organizations have to recognize the importance of the ideological aspects of development work (Sohn et al. $2011 \mathrm{~b}$, forthcoming).

As an emerging donor, the Korean government seems to be committed to implementing its ODA policy effectively and managing its partnership with civil society efficiently within the system. However, as a relative beginner in terms of giving aid, the Korean government also faces several challenges when carrying out aid: uncertainty about its public commitment, an unclear vision and philosophy regarding ODA, an insufficient civil society partnership program, and a need for clear policy objectives for NGO support programs.

To begin with, whether the government can keep its public commitment is uncertain, due to economic and political factors. Although the government 
is willing to enlarge the ODA budget for NGO partnership, up to 90 billion won by 2015, no one can tell for sure whether its pledges will be fulfilled in the current international financial crisis. Moreover, the domestic political environment renders the commitment uncertain. Depending on the results of the upcoming presidential election in 2012 , the commitments of the previous administration could be compromised. Without a political consensus on the issue, it is hard to aliocate funds for $O D A$ as plaumed, and especially for a government-civil society partnership within the scheme.

Furthermore, the Korean government has not developed a shared vision and philosophy for ODA. The current strategies give guidance for Korean ODA in some respects, but without common policy goals it is hard to achieve desired outcomes. While Korea has so far focused only on increasing the volume of ODA, it lacks a clear recognition of development NGOs and their importance. Since NGOs are valuable partners in administering better aid, the government and KOICA need to elucidate whether they perceive development NGOs as complementary or equivalent partners, so as to make the best of their role.

What is more, the Korean government needs to devise a variety of civil society partnership programs, whether they be service delivery or capacity-building programs. Because KOICA is an implementing institution, current NGO support is solely administrative, and chiefly financial. Even though KOICA runs diverse programs in cooperation with civil society, such as the Invitational Training Program, the Korea Overseas Volunteers Program, Emergency Relief, and so forth, these programs are at the most basic level.

To improve the capacity of development NGOs, KOICA established the International Development Education Academy in 2010. However, it is said that the curriculum and system are not yet fully developed. Also, the KCOC, as a member of civil society, has been commissioned by KOICA to offer a couple of courses in NGO capacity building, but that is not enough to meet growing demands from development NGOs. For long-term progress, the government and KOICA have to invest in both organizational and human resource capacity building, other than simply offering financial support, such as utilizing local expertise, developing an educational curriculum, and providing civic education on development.

Given that the general and presidential elections are just around the corner in 2012, we can easily predict that the volatility around international cooperation policies will be increasing. However, Korea is unique in that both conservative and progressive administrations have exhibited a positive stance toward international development cooperation over the last 20 years. During the economic crises of 1990 s and 2000 s, the budget for ODA was protected, and even increased, which means ODA became one of the top priority agenda items for any administration, regardless of its ideological position. In line with this observation, it would be very interesting to see what the partnership will be like between 
the Korean government and NGOs.

\section{REFERENCES}

Advisory Group on Civil Society and Aid Effectiveness. 2007. "Civil Society and Aid Effectiveness. Issues Paper," OECD/DAC W/P-EFF. September 17. DCD/DAC. 2011. How DAC members work with civil society organizations: an Overview. Paris: OECD.

Edwards, M. and D. Hulme. 1996. Too Close for Comfort? The Impact of Official Aid on Nongovernmental Organizations. World Development 24: 6-28.

Edwards, M. 2004. Civil Society: Theory, History and Alternative Reconstruction. Seoul: Corea Literary Agency (in Korean).

Ferris, E. 2005. Faith-based and secular humanitarian organizations. International Review of the Red Cross 87(858): 311-325.

Fowler, A. 2000. NGO futures: beyond aid: NGDO values and the fourth position. Third World Quarterly 21(4): 589-603.

Han, J.-K. 2009. The International Development Policies of the Korean Public: the Case of ODA Watch. Paper presented at the 2009 Gwangju International Peace Forum: The Challenges of Korean Civil Society for New ODA Horizon, Gwangju, South Korea. May 16-17, 2009 (in Korean).

Han, J-K. 2010. The Trend of International Development NGOs and its Implication on Korean Development NGOs. Paper presented at the annual conference of Korean Association of International Development and Cooperation: Korea's Joining DAC and Hosting HLF: Significance and Tasks, Seoul, South Korea, January 22, 2010 (in Korean).

Joo, S., S. Lee, and Y. Jo. 2006. The Explosion of CSOs and Citizen Participation: An Assessment of Civil society in South Korea 2004-CIVICUS Civil Society Index Report for South Korea. Seoul: The Third Sector Institute (in Korean).

Kappaz, C. 2001. The Evolving Role of Advocacy. In Going Global: Transforming Relief and Development NGOs, eds. Marc Lindenberg and Coralie Bryant. Bloomfield: Kumarian Press.

KCOC. 2007. KCOC Code of Conduct. Seoul: KCOC (in Korean).

Kindornay, S. 2011. From Aid to Development Effectiveness: A Working Paper. The North-South Institute.

Lee, Y.-H. 2009. Development. Seoul: Yonsei University Press (in Korean). Lewis, David. 1998. Development NGOs and the Challenge of Partnership: Changing Relations between North and South. Social Policy and Administration 32(5): $501-512$.

OECD. 2001. Citizens as Partners: Information, Consultation and Public Participation in Policy-making. Paris: OECD.

OECD/DAC. 2008. Development Co-operation of the Republic of Korea-Special 
Review. Paris: OECD.

Smillie, 1. and H. Helmich, eds. 1999. Stakeholders: government-NGO partnerships for international development. London: Earthscan Publications.

Smillie, 1. 1994. Changing partners: Northern NGOs, Northern governments. Voluntas 5(2): 155-192.

Sohn, H.-S and Y.-H. Yoo. 2009. The Challenges of Korean Development NGOs: Constraints and Opportunities. Oughtopia: The Journal of Social Paradigm Studies 24(1): 5-31.

Sohn, H.-S., B.-C. Jeong, S.-S. An, J.-K. Han, and P.-K. Park. 2010. Evaluation of KOICA's NGO Support Program. Seoul: KOICA (in Korean).

Sohn, H.-S., J.-K. Han, and P.-K. Park. 2011. A Study on State-Civil Society Cooperation for Enhancing Development Effectiveness in Korea. Seoul: KOICA (in Korean, forthcoming).

Sohn, H.-S., J.-E. Shin, and J.-H. Lee. 2011. An Analysis of Korean Development NGO Capacity and Capacity Building. Seoul: KOICA (in Korean, forthcoming). 


\section{ENDNOTES}

'A definition of 'development effectiveness' is not commonly agreed upon by various stakeholders such as the World Bank, OECD DAC, CSOs, etc. In 2011, the NSI identified four prossible categories for the term: organizational effectiveness, coherence, outcomes from uid, and overall development outcomes. These categories are neither mutually exclusive not exhaustive, and some development actors' understanding of the term overlap categories (Kindornay 2011).

In the Accra Action for Agenda, Paragraph 20 also states that,

a) W' invite CSOs to reffect on how they can apply dire Paris primipies of aid effectiveness from a CSO perspective.

b) We welcome the CSOs' proposal to engage with them in a CSO-led multi-stakeholder process to promote CSO development effectiveness. As part of that process, we will scek to i) improve co-ordination of CSO efforts with government programmes, ii) enhance CSO accountability for results, and iii) improve information on CSO activities.

c) We will work with CSOs to provide an enabling environment that maximizes their contributions to development.

"Faith-based organizations: a religious congregation (church, mosque, synagogue or temple); an organization, program ot project sponsored/hosted by a religious congregation; a non-profit organization founded by a religious congregation or religiously-motivated incorporators and board members that dearly states in its name, incorporation or mission statement that it is a religiensly motivated institution; a collaboration of organizations that clearly and explicitly includes organizations from the previously described categories" (Ferris 2005).

' In 2007, 23 South Korean missionaries were captured and held hostage by members of the Taliban while passing through Ghanzni Province of Afghanistan. Of the 23 hostages captured, two of the men wete executed. Later, with negotiations making progress, the remaning hostages were released. Only includes project expenditures and administrative costs (The KOICA Voluntecrs Program, public awareness projects, emergency relief, and KCOC support are excluded. Resources from 1995 to 2009 ate based on the "Statistics on the NGO Support Program" of the KOICA NGO Team. Statistics of 2010 and 2011 are from the KOICA website.

"Resources from 1995 to 2009 are based on "Statistics on the NGO Support Program" of the KOICA NGO Team. The statistics for 2010 and 2011 are from the KOICA website. The figures for countries and projects are from the KOICA website.

This observation has been confirmed during interviews on October 31 and November 1, 2011, with KOICA Vice President, Choong-sik Han, KOICA Public-Private Partnership Office Team Leader, Sook-hee Baek, and former Public-Private Partnership Office Team Leader. Hyun $\mathrm{Na}$.

"Accountability is the means by which individuals and organizations report to a recognized authority and are held responsible for their actions" (Edwards and Hulme 1906)

"NGO advocacy is speaking out for policy change and action that will address the root causes of problems confronted in development and relief work, and not simply speaking out to alert people of a problem in order to raise funds to support operational work" (Kappaz 2001). 